\title{
記憶障害例に対して残存する視覚記憶を利用したPQRST 法の効果
}

\author{
高 原 世津子 ${ }^{*}$ 野 間 俊 - ${ }^{* *}$ 種 村 留 美 $^{* * *}$ \\ 上床 輝 久 ${ }^{* * * *}$ 種 村 純 ${ }^{* * * * *}$
}

\begin{abstract}
要旨：欧米で広く推奨されている学習方法である PQRST 法は, Preview, Question, Read, SelfRecitation, Testからなり, 他の記憶ストラテジーに比べ有効であることが示されている。今回われ われは，両側側頭葉前下部，前頭葉眼窩面に広範な脳内出血を認め，受傷後 7 カ月半を経過した健 忘症患者に PQRST 法を用いた記憶訓練を施行し，良好な結果を得たので報告する。PQRST 法は本 来言語的手がかりを使用するが，今回は，症例に相対的に残存していた視覚性記憶もあわせて利用 した。PQRST 法は記憶障害患者に深い情報処理を促し，文章の理解と保持を促進したことが示唆さ れた。また，Baddeleyらによってその有効性が確認されている，誤りなし学習法についても検討し， それが追認された。また, 学習時にのみ示していた軽度保続に対しても, 誤りなし学習が有効であ ることが示唆された。約 2 力月の治療的介入の結果, 検查成績の向上とともに, 実際の生活場面に おいてもエピソード記憶が改善し, 症例は社会復帰を果たした。
\end{abstract}

(高次脳機能研究 $25 （ 3 ） ： 251 ２ 58 ， 2005$ )

Key Words : PQRST 法, 誤りなし学習, 記憶障害

PQRST approach, Errorless learning, Memory dysfunction

\section{はじめに}

PQRST 法はSQ3R 法と類似した方法で, Robinsonによって提唱された。欧米では広く推奨 されている学習方法である（Werner 2004）。 Preview（全体的文脈を学習するためにざっと目を 通す)，Question（テキストのキーとなる概念につ いて尋ねる)，Read（質問に答えることを念頭に 置いて読む)，Self-Recitation（読み終わった情報 を能動的に覚えこむ)，Test（質問に答えることに よってみずから再検討する）からなる。PQRST法 は内的記憶戦略法の 1 つで, 言語的記憶戦略法の 代表的なものであり，テキスト情報を記憶する学 習法である。

本論文では，左前頭葉，両側側頭葉（左＞右） に広範な脳内出血を認め, 記憶障害を呈した症例
に対して，PQRST 法を施行した成績を報告する。 本症例は相対的に視覚性記憶が保持されていたた め，通常の言語的手がかりを用いる PQRST 法以 外に, 視覚的手がかりを利用したPQRST 法を考 案し, 記憶回復への介入を行った。

誤りなし学習は, Baddeleyら（1994）によって, その有効性が確認されている。健忘症患者におい ては，潜在記憶は比較的保たれているものの，学 習時の誤りを消去する役割を担う顕在記憶の障害 が大きいために，誤りなし学習はとくに重要であ る。「健忘例は, 学習過程において誤りをおかさな いほうが学習効率が良好である」との仮説 (Baddeleyら 1994) を検証するために，われわれ は, 誤りなし学習と誤りあり学習の両方法を用い て検討することにし，PQRST 法と組み合わせた訓 練法を考案し，その成果を検討した。その結果，
*京都大学医学部附属病院 リハビリテーション部 $\bar{\mp} 606-8507$ 京都市左京区聖護院川原町 54

**京都大学大学院医学研究科 精神神経科

****京都大学医学部 保健学科作業療法学専攻

*****京都博愛会病院 精神科

****** 川崎医療福祉大学 感覚矯正学科 
検査成績の向上とともに, 生活レベルにおいても 良好な結果を得たので報告する。

\section{I. 症例}

症例は 46 歳の男性で, 生来左利きであったが, 書字と箸のみ右に矯正, 絵は左手で描いていた。 高等学校卒業後, 看板業を営むかたわら, 中央卸 売市場で食品の運搬のアルバイトをしていた。趣 味は絵を描くことであった。性格傾向は快活で面 倒見のよいほうであったが，受傷後，記憶障害へ の認識が高まった時期より，自信を喪失し自分を 責める日々を過ごしていた。家族構成は，妻と息 子 3 人の 5 人である。

現病歴：2000年 2 月 18 日, 中央卸売市場にお いて, トラック運転中転落し, 自分のトラックに 轢かれるかたちで左後頭部を激しく打撲した。脳 内出血, および脳挫傷を認め, 水頭症も合併して いたため, 入院治療を開始した。4月 14 日, 側脳 室-腹腔内シャント術が施行された。その後 3 回の 痤攣発作を起こし, 徘徊行動が始まった。 3 回目 の発作によって転倒し後頭部打撲, 左後頭葉に出 血を認めた。その後徐々に徘徊は落ち着き病識も 出現してきたが, 高次脳機能障害が残存するため, リハビリテーション目的で 9 月 21 日に京大病院精 神科神経科に転院した。9 月 22 日の脳波では，基 礎律動は $6 \mathrm{~Hz}$ の $\theta$ 波で， $\alpha$ 波はほとんど見られず, 多発性の高振幅徐波が両側に認められた。当院に おいて 10 月 3 日より作業療法を開始した。

放射線学的所見：9月 16 日（発症 7 力後）の 頭部 X 線 CT を図 1 に示した。新しい病変部位や 萎縮を認めなかった発症 3 年後の MRI FLAIR 画像 (図 2) 所見では, 両側側頭極を含む側頭葉前下部, 両側前頭葉眼窩面 (左>右), 左島葉から左側脳室 前角周囲白質に高信号域を認めた。

神経学的・神経心理学的所見: 受傷後 7 力月半 経過時の所見は以下のとおりであった。軽度の右 片麻痺 (Brunnstrom Stage VI, 簡易上肢機能検査 右 84/100 点，左 94/100 点）を有していたが，小 脳症状, 感覚障害はなく, 右手は日常生活におい て実用的に使用していた。日常行動の中で，情動 や注意に問題はなく, 治療者に対する礼節は保た れていた。エピソード記憶の障害は重度で, 食事
内容は，口に入れ目前から食べ物が消えた直後に はもう忘れてしまっていた。過去の記憶について も, 子供たちの年齢や学年は $2 \sim 3$ 年若く述べて いた。記憶障害に対する病識を強く持っており, 検査成績が悪いと自分を責め，抑うつ的であった。 このため, 多くの神経心理学的評価を実施するこ とは困難であった。ウェクスラー記憶検査（以下 WMS）日本訳試案（小山 1985）の結果は次のと おりであった。記憶指数 57 [現在・個人的情報 $1 / 6$, 見当識 $1 / 5$, 精神統制 $1 / 9$, 長文記憶 $1 / 24$, 数唱課題 $7 / 15$ (順唱 $4 / 8$, 逆唱 $3 / 7$ ), 視覚記銘 $11 / 14$, 聴覚記銘 $0 / 21]$ であり，聴覚記銘の著し い低下に対して，視覚記銘は保たれており，短期 記憶の障害は相対的に軽度であった。言語指示に

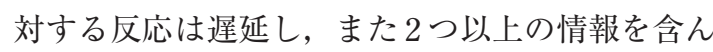
だ言語指示は理解できなかった。 3 人の息子のう ち， 2 人の名前は答えることができなかった。書 字において保続を認めた（「京都大学医学部附属病

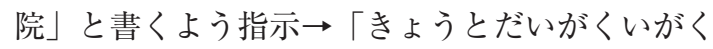
ぶふぐぞくびょういんいん」）が，保続は他の場面 において認めることはなかった。言語の入出力い ずれにおいても処理能力が低下していた。SLTA では, 呼称 $16 / 20$, 語の列挙 $1 / 15$, 口頭命令 $5 / 10$, まんがの説明は段階 4 であり，錯語・言いよどみ はなく, 統語・音韻はよく保たれていた。軽度健 忘失語が考えられた。記憶検査成績には失名詞の 要因も関与していると考えられた。以上の検査結 果および検査場面での観察を通して, 注意機能に も軽度の低下が認められた。

絵筆の使い方や，はさみの使い方は作業療法介 入直後から正しかった。新しく学習した勒細工に おいて, 作業工程の記憶はそれぞれのセッション ごとに忘れていて，そのつど教示する必要があっ たが，新しく学習したはずの難度の高い道具の使 い方は速やかに学習し, セッションが変わっても 覚えていた。すなわち，本例においては，手続き 学習が保たれていたと解釈することができる。

本症例は落胆が激しく描画に対して自信を失っ ていたので，描画能力の改善と自信の回復を目的 として，革細工を導入した。道具に慣れることか ら開始し，作品の難易度と大きさを徐々に高めた。 道具の使い方や作品に対して頻繁に賞賛を与え, 


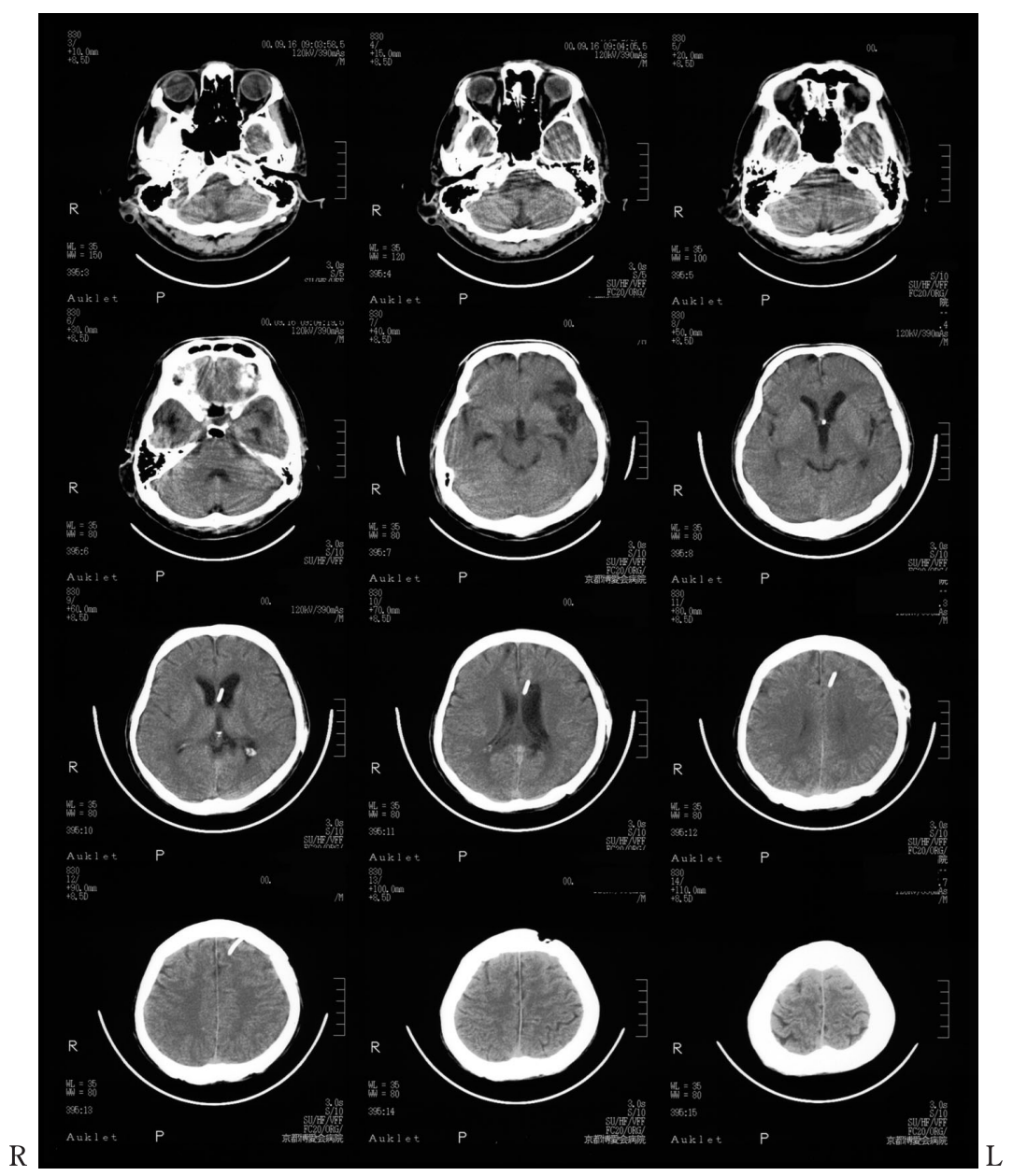

図1頭部X線CT（2000年9月16日撮影）

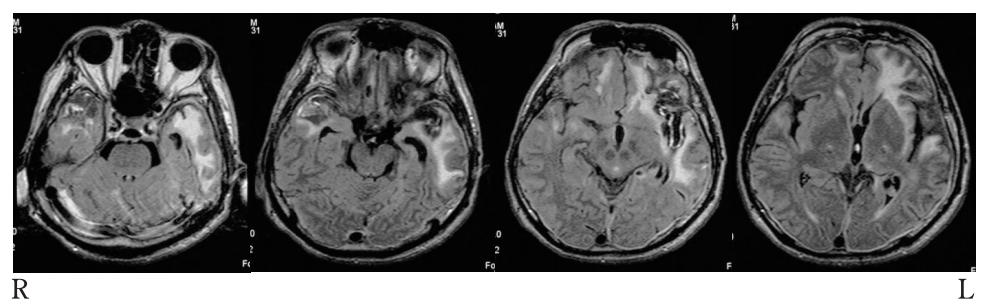

図2 MRI FLAIR画像（2003年2月20日撮影）

両側側頭極を含を側頭葉前下部, 両側前頭葉眼窩面 (左 $>$ 右), 左島葉から左側脳室前角周囲白質に高信号域を認めた。 

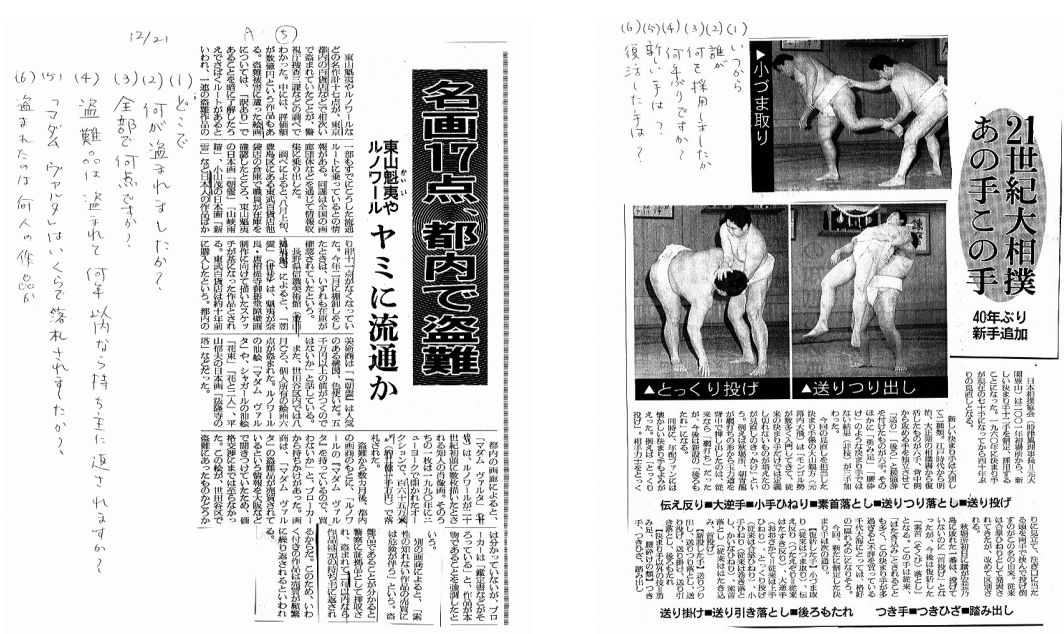

図3 文章課題と視覚課題

つねに支持的に接することを心がけ，成功体験へ と導いた。3 作品の作製を通して自信を回復して いった。

作業療法開始当初から記憶の代償のためにメモ リーノートを導入した。メモリーノートの必要性 は理解しているものの，「書かなくてはいけない」 ということに強いストレスを感じていた。エピソ 一ドをあげると，食事時に箸箱の中に副食の切れ 端を入れ，部屋に戻ってからそれを見てノートに 記載しょうとしたが，副食の一部を見ただけでは 思い出せず，ストレスとなり，食欲が徐々に低下 していった。このため，記入することを習慣にす ることを第一と考え，食事内容を記入してから食 事をとるようにし，病棟でのエピソードなどは治 療者らと一緒に記載するようにした。

開始後 1 力月経過時には記憶の欠損をノートを 見て補うことができるようになってきた。

\section{II. 介入方法}

PQRST 法は，文章のみの課題（文章課題）と新 聞記事に写真を含んだ課題（視覚課題）を比較検 討した。実際に用いた新聞の切り抜き記事の文章 課題と視覚課題の例を図 3 に示した。

記憶障害患者における誤りなし学習の有効性を 検証するために，䛊りなし学習と誤りあり学習を 用い，PQRST法と組み合わせた記憶および学習障 害への介入を，一事例デザインによる観察法で行
った。

PQRST 法は，2000 年 11 月 28 日より予備的訓練 として導入し，12月 13 日から検討を開始した。 一事例デザインは，次のように計画した。A期： 何もストラテジーを用いないベースライン，B 期：文章課題・誤りあり学習, $\mathrm{B}^{\prime}$ 期：文章課題・ 誤りなし学習, C 期 : 視覚課題・誤りあり学習, $\mathrm{C}^{\prime}$ 期：視覚課題・誤りなし学習, $\mathrm{A}^{\prime}$ 期最終評価： 文章課題 $\mathrm{B}$ と同一課題だが，自由にストラテジー を使ってよい。 $\mathrm{A}$ 期， $\mathrm{B}$ 期と最終評価 $\mathrm{A}^{\prime}$ 期は同じ 記事（5 種類）を用いた。各期は 5 セッションか らなり，1セッションずつ異なる新聞記事の切り 抜きを用いた。1つの新聞記事ごとに 6 項目の設 問を設けた（図 3)。Previewでは本症例がざっと 音読し，読めない部分がある場合は治療者が教示 した。Questionでは6つの設問ごとに記事中から 本症例と治療者が答を見つけ，赤で線を引いて目 立つようにした。Readでは答を確認しながら読み, Self-Recitation では設問に沿って能動的に覚えこ もうとした。約 10 秒後の Testにおいて治療者が 質問し，本症例が答えた。なお誤りなし学習では， 本症例が即答できない場合に，すぐに最初の語を ヒントとして与え，誤りを惹起しないようにした。 この時，新聞記事は見ないで答えた。PQRST法は 作業療法室において 1 セッションにつき 1 記事を 用いて施行し，翌年 2 月 6 日に終了した。 


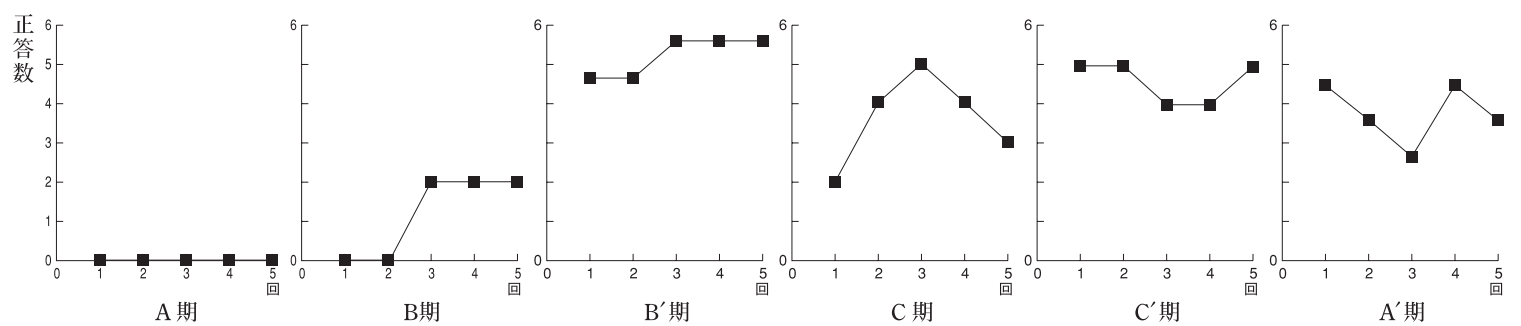

図4 文章課題と視覚課題のPQRST法による詋りあり，誤りなし学習の経過 $\mathrm{A}$ 期：ベースライン, B期：文章課題 誤りあり学習, $\mathrm{B}^{\prime}$ 期：文章課題 誤りなし学習, $\mathrm{C}$ 期 $:$ 視覚課題 誤りあり学習, $\mathrm{C}^{\prime}$ 期：視覚課題 誤りなし学習, $A^{\prime}$ 期：最終評価

\section{III. 結 果}

PQRST 法の経過を図 4 に示した。図の縦軸は正 答数を, 各期の横軸は施行回数である。何もス卜 ラテジーを用いない A 期では正答はなかった。ま た， B 期は正答率が低い。これは一度誤った答を すると，ずっと同じ誤りを繰り返す場合が多かっ たためである。たとえば，高校野球ポスターコン クールの記事において「何部に所属していますか」 という設問に対し，「ラグビー部」と答えるべきと ころ, Readで「野球部」と答えてしまうと, SelfRecitationにおいてもTestにおいても「野球部」 と答えた。また， B 期， C 期に共通する誤り方と しては，異なった設問項目に対して「何年・何 点・何円」など数字で答えることを要求するよう な設問にすべて「 $「 2$ 年・ 2 点・ 2 億円」のように同 じ数字を当てはめて答えることが，10課題中 5 課 題に認められた。 $\mathrm{B}^{\prime}$ 期， $\mathrm{C}^{\prime}$ 期の誤りなし学習は明 らかに成績がよく，言語，視覚の課題特性を超え て誤りなし学習の有効性を示した。B期， C 期の 誤りあり学習では視覚課題の成績がよかった。べ ースライン $\mathrm{A}$ 期および $\mathrm{B}$ 期と，最終課題は同一内 容であったが，A期では正答数は $0 / 30 ， \mathrm{~B}$ 期は 6/30，最終評価では $21 / 30$ と，最終評価での成績 は著明に改善した。PQRST 法訓練前後のWMS 日 本訳試案の結果を表 1 に示した。すべての項目に おいて成績の改善を認めたが，見当識が著明に向 上した。初期評価において成績のよかった視覚記 銘は満点になり，0点であった聴覚記銘も改善し た。しかしなお長文記憶の改善はわずかであった。
表 1 WMS (日本訳試案) 結果の介入前後の変化

\begin{tabular}{c|c|c}
\hline & 介入前 & 介入後 \\
\hline \hline 現在·個人 & $1 / 6$ & $2 / 6$ \\
見当識 & $1 / 5$ & $5 / 5$ \\
精神統制 & $1 / 9$ & $2 / 9$ \\
長文記憶 & $0.5 / 24$ & $1.5 / 24$ \\
数唱 & $7 / 15$ & $11 / 15$ \\
視覚記銘 & $11 / 14$ & $14 / 14$ \\
聴覚記銘 & $0 / 21$ & $4.5 / 21$ \\
\hline 記憶指数 & 57 & 77 \\
\hline
\end{tabular}

\section{IV．訓練後の日常生活活動の変化}

日常生活においても他科受診の予定を記憶でき るようになったり, 病棟で起こった他患者らとの 出来事を覚えていたり, 食事内容の一部を記憶す ることができるようになり, エピソード記憶の改 善を認めた。スタッフの名前は，まず顔を見て， 本症例の手掌にスタッフの姓を漢字で書き，それ を読んで言語化するという方法をとり，覚えるこ とができるようになってきた。本症例に残存して いた視覚性記憶を利用し, 顔と漢字を視覚的に結 合させ，それを言語に変換するという方法をとり， 新しい意味記憶の学習が成立した。過去の記憶に ついても，作業療法開始時には子供たちの年齢を $2 \sim 3$ 年若く述へ，逆向性健忘を認めたが，介入 終了時には，年齢を正しく述べるようになっただ けではなく, 長男が大学受験をする予定であるこ となど，現在の状況を正確に把握できるようにな った。

本症例は当院退院時, 障害の性質, 利用可能な 
ストラテジーを説明したうえで, 当院の地域ネッ トワーク医療部, リハビリテーションセンターに 引き継いだ。その後職業リハビリテーション機関 も介入し 2 カ月半に及ぶワークトレーニングを経 て, 2002 年 3 月には自動車会社に洗車業務として 就職が決定し職業復帰を果たした。新しい職場に おいても得意な絵画の能力を発揮し，同僚の似顔 絵を描いたり, イベントの際のポスターを描くな ど，いきいきとした社会参加を果たしている。

\section{V. 考察}

Glasgow ら（1977）は，頭部外傷によって健忘 症を呈した Ms.Jに，リハーサルストラテジーと 組織化ストラテジーを組み合わせた PQRST 法を 適用し，通常のリハーサル条件や単に 1 回読むだ けのコントロール条件に比べて有効であることを 述べた。PQRST 法は記憶障害患者の文章の理解と 保持を促進することが知られている（Rodger 1992)。健忘症に関する符号化障害仮説では, 自発 的な意味処理がなされないことが, 記憶の障害を もたらすと考えるが，PQRST法により，意味処理 を自発的に行うことを促すと考えることができる。 また, 記憶材料はさまざまな深さで処理すること ができ，処理が深いほど記憶の保持もよくなる (Craikら 1972)。PQRST法ではより注意深く思考 すること，より深層の処理過程を使用する必要が ある (Rodger 1992)。本症例もべースライン A 期 および $\mathrm{B}$ 期と, 最終課題は同一内容であったが, 最終評価での成績は向上した。これはPQRST 法 によって深い水準の情報処理を促し, 最大能力の レベルで安定化した結果であると解釈できる。こ のように情報処理能力を改善させたことが，本症 例の社会生活能力の向上をもたらしたと考えるこ とができる。

健忘症患者では，学習における誤りを消去する 役割を担う顕在記憶の障害が大きいために, 間違 えれば間違えるほど，その誤りを訂正できず（䛊 りに引きずられて), 正答に到達できなくなると考 えられ, 可能なかぎり䛊りをおかさないことが重 要である（三村 1998）。すなわち, 健忘症患者に おいては誤りなし学習はとくに重要である。今回 のわれわれの症例においても，B期， $\mathrm{C}$ 期の誤り
あり学習では正答できなかったものは $36 / 60$ に及 ぶが，そのうち誤った答に引きずられた誤答が 9 回出現し, 誤りが定着してしまう傾向があること が示された。この結果はいったん誤って表出され た反応の後に出現した保続の症状であると考えら れる。本例のように日常生活場面では保続を示す ことはないが，学習場面になると保続が出現する 症例では, 学習において誤りを生じさせないこと が重要であり，誤りなし学習の手続きが有用と考 えられる。誤りなし学習は, 誤りあり学習よりも 成績がいいと考えられ，「健忘例は，学習過程にお いて誤りをおかさないほうが学習効率が良好であ る」との仮説は検証された。またこのことは，軽 度保続を示す症例においても有効であることが示 された。

本症例では B 期，C 期の誤りあり学習では視覚 課題の成績がよかった。PQRST 法は記憶方略の中 でも言語的手がかりを用いる方法に分類されてい るが（三村 1999），本症例に対しては相対的に保 たれていた視覚性記憶もあわせて利用し，記憶回 復への介入を行った。言語と視覚の両方の要素を 組み合わせることで有効性が増す場合もある（三 村 1999）といわれており，本症例における改善は, 人の名前を漢字に書いてから想起するというよう に，練習によって獲得された言語的手がかりと， 残存していた視覚性記憶の相乗効果によると考え ることができる。しかし，誤りなし条件では文章 課題と視覚課題の成績はほぼ同等であり，言語 的・視覚的課題特性を超えて誤りなし学習が効果 的であった。

原（2002）は，日本版リバーミード行動記憶検 査の標準プロフィール点を用いて記憶障害患者 18 例の急性期からの改善経過を調査しているが，約 8〜 12 カ月の時期にはプラトーとなるという。今 回のわれわれの症例は, 受傷後 7 カ半経過した 後も大きな改善を認めた。自然経過や非特異的訓 練によって注意機能が向上し，日常生活場面にお ける改善をもたらした可能性は否めないが，はじ めに徹底した支持的な作業療法により本症例の自 信を高め，次に正確な評価結果にもとついて，視 覚性記憶を利用しながら，かつ PQRST 法によっ て情報処理の水準を深めるという治療的介入が大 
きな改善をもたらしたことを示唆している。

今回われわれは，良好な視覚性記憶を利用する ために, 文章課題と視覚課題の両方を用いたが, 文章課題は [文章のみ], 視覚課題は [文章+視覚］ であり，後者はより記憶に有利な材料を含んでい ると考えられる。このことを, 今回の研究の問題 点であると受け止め，今後の課題としたい。

\section{文献}

1) Baddeley, A. \& Wilson, B. : When implicit learning fails : Amnesia and the problem of error elimination. Neuropsychologia, 32 : 53-68, 1994.

2 ) Craik, F. I. M. \& Lockhart, R. S. : Levels of processing : A framework for memory research. J. Verb. Learn. Verb. Behav., 11 : 671-684, 1972.

3 ) Glasgow, E., Barrera, M. \& Lawinsohn, M. : Case studies on remediating memory deficits in braindamaged individuals. J. Clin. Psychol., 33 : 10491054, 1977.

4 ) 原 寛美：記憶障害とリハビリテーション一機
能訓練. 総合リ八, $30: 313-319,2002$.

5 ) 小山充道 : 脳障害者の心理臨床。病める心のリ ハビリテーション。学苑社, 東京, 1985, pp. 4854.

6 ) 三村 將：記憶障害のリハビリテーション一間 違った方が扎ぼえやすいか? 努力した方が打ぼ えやすいか?一。失語症研究, $18: 136-145$, 1998.

7 ) 三村 將：記憶障害のリハビリテーション一実 際的見地から。精神医学, 41:49-54, 1999.

8 ) Rodger, W. : Memory therapy in practice. In : Clinical management of memory problems (eds Wilson, B. \& Moffat, N.) . 2nd Ed.,Chapman \& Hall, London, 1992 (綿森淑子, 監訳：5 章 記憶 訓練の実際。記憶障害のリハビリテーション. 医学書院, 東京, 1997, pp.135-172).

9 ) Werner, S. : The PQRST method of studying \& SQR3 - five steps to master your textbook. http://arbeitsblaetter.stangl-taller.at/LERNTECHNIK/PQRST.shtml, 2004. 
Abstract

\title{
Effectiveness of PQRST approach on a patient with memory dysfunction
}

\author{
Setsuko Takahara* Shunichi Noma** Rumi Tanemura*** \\ Teruhisa Uwatoko ${ }^{* * * *}$ Jun Tanemura****
}

The PQRST method of studying is widely promoted in Western nations. This strategy consists of five steps : Preview, Question, Read, Self-Recitation and Test, which revealed relative effectiveness compared to the other strategies. Now we are going to report on a successful case of PQRST training for a duration of 2 months, with a patient who had memory problems seven and a half months after his brain injury. Usually PQRST approach uses verbal cues, but we also used visual cues because his visual memory was relatively intact. In this case, it was hypothesized that the PQRST approach would stimulate his retention ability would improve. We also examined an erroeless learning approach which Baddeley had disclosed the efficacy of, and this we confirmed. The patient showed a slight degree of perseveration only when studying, it is all the more certain that studying is an effective means of treatment. After treatment his test score improved significantly. He gained progressive performance on episodic memory and daily living activities, and finally he returned to his employment.

* Department of Occupational Therapy, Rehabilitation Units, Kyoto University Hospital. 54 Syogoin Kawaharacho, Sakyo-ku, Kyoto 606-8507, Japan

** Department of Neuropsychiatry, Graduate School of Medicine, Kyoto University

*** Occupational Therapy Division, School of Health Sciences, Faculty of Medicine, Kyoto University

***** Department of Psychiatry, Kyoto Hakuaikai Hospital

****** Department of Sensory Sciences, Kawasaki University of Medical Welfare 